\title{
Formation of Cobalt Ferrites Investigated by Transmission and Emission Mössbauer Spectroscopy
}

\author{
Vit Prochazka, Anezka Burvalova, Vlastimil Vrba, Josef Kopp \\ and Petr Novak* \\ Department of Experimental Physics, Faculty of Science, Palacký University, 17. listopadu 1192/12, \\ 77146 Olomouc, Czech Republic \\ *Corresponding author: E-mail:petr.novak@upol.cz
}

Received: 09-06-2019

\begin{abstract}
This study focuses on cobalt and iron ordering within a ferrite structure $\mathrm{Co}_{\mathrm{x}} \mathrm{Fe}_{3-\mathrm{x}} \mathrm{O}_{4}$, formed during a solid-state reaction of $\alpha-\mathrm{Fe}_{2} \mathrm{O}_{3}$ and $\mathrm{CoCl}_{2}$. A unique combination of transmission and emission Mössbauer spectroscopy was employed to inspect selectively the positions of iron and cobalt atoms in the structure. The comparison of transmission and emission spectra allowed the determination of tetrahedral and octahedral positions occupation. The presented method of combining the two Mössbauer spectroscopy techniques is suitable for any compounds containing both iron and cobalt atoms. Additional information concerning the samples composition and morphology were obtained by X-ray powder diffraction and scanning electron microscopy. An increased level of Co atoms incorporation into the structure of ferrite was revealed when higher amounts of Co entered the reaction.
\end{abstract}

Keywords: Cobalt ferrite, Mössbauer spectroscopy, degree of inversion, solid state reaction

\section{Introduction}

Cobalt ferrites are thoroughly investigated because of their magnetic, optical and electrical properties and their wide range of technological applications such as transformer cores, batteries, recording heads, ferrofluids, biomedical applications including biosensors and cellular therapy, catalysis and sensors. ${ }^{1-10}$ Cobalt ferrite is a magnetically hard material with a high positive magnetic anisotropy constant, good chemical stability, high mechanical hardness and high level of magnetization. Furthermore, it does not pose a risk to the biological environment. ${ }^{1,11}$ Most of the physical properties of this ferrite strongly depend on the size and shape of the particles. ${ }^{12}$ Cobalt ferrite nanoparticles are also photomagnetic materials which demonstrate an interesting change in coercivity induced by light. ${ }^{13}$

The specific properties of cobalt ferrites are governed by their microstructural arrangement that is formed during their synthesis. Therefore, it is important to understand the mechanisms of their formation and the dynamics of their synthesis. Ferrites form the spinel structure $\left(\mathrm{AB}_{2} \mathrm{O}_{4}\right)$. The basic cell of $\mathrm{MeFe}_{2} \mathrm{O}_{4}$ spinel ferrite, where Me refers to the metal atom, is a cubic close-packed structure containing 32 anions. ${ }^{14}$ Cations occupy two different crystallographic sites, namely A and B positions. Cations localized at A positions are surrounded by 4 oxygen atoms forming a tetrahedron, thus this position is also referred to as tetrahedral. Cations in B positions are enclosed by six oxygen atoms forming octahedron. Therefore, the B position is called octahedral. Each basic cell contains 8 tetrahedral (A) positions and 16 octahedral (B) positions. ${ }^{1,14,15}$

Cobalt ferrites can be prepared by a number of different methods such as solid-state reaction, ${ }^{16-18}$ mechanochemical synthesis, ${ }^{12}$ combustion method, ${ }^{19-21}$ co-precipitation, ${ }^{22-24}$ hydrothermal synthesis, ${ }^{25-27}$ sol-gel method ${ }^{28,29}$ or reverse micelle technique. ${ }^{30,31}$

Ferrites are divided into several groups according to their cations distribution. ${ }^{14,32}$ For the normal structure the formula $(\mathrm{Me})\left[\mathrm{Fe}_{2}\right] \mathrm{O}_{4}$ is usually used. Square and round brackets denote the cations' association to the octahedral and tetrahedral positions respectively. In the normal structure all the non-iron cations are located in tetrahedral positions. The opposite extreme, the inverse structure, has all the non-iron cations in octahedral positions according to the formula $(\mathrm{Fe})[\mathrm{MeFe}] \mathrm{O}_{4}$. The transition state between these two extremes can be represented as $\left(\mathrm{Me}_{1-\delta} \mathrm{Fe}_{\delta}\right)$ $\left[\mathrm{Me}_{\delta} \mathrm{Fe}_{2-\delta}\right] \mathrm{O}_{4}$, where $\delta$ is called the degree of inversion. It is equal to 0 for the normal spinel structure and to 1 for the inverse spinel structure. 
The degree of inversion expresses the ratio of cations at different crystallographic positions. Nevertheless, its determination in cobalt ferrites is rather challenging task because Fe and Co atoms have similar atomic scattering factors and their identification by X-ray powder diffraction is limited. Cobalt ferrites usually form the inverse structure, where $\mathrm{Co}^{2+}$ ions are located only in $\mathrm{B}$ positions and $\mathrm{Fe}^{3+}$ ions are situated in both $\mathrm{A}$ and $\mathrm{B}$ positions. However, the degree of inversion might not be constant and it can depend on the previous heat treatment. ${ }^{33-36}$

Within this study we utilized emission Mössbauer spectroscopy and transmission Mössbauer spectroscopy for investigation of the local surroundings of $\mathrm{Co}$ and $\mathrm{Fe}$ atoms. The transmission arrangement inspects the local surroundings of iron atoms. On the contrary, the emission arrangement offers information selectively on the local structure around the ${ }^{57} \mathrm{Co}$ atoms. The combination of these two complementary information allows to determine the degree of inversion. Moreover, the correlation of cobalt and iron Mössbauer spectra could bring new enlightenment to the problem of cobalt ferrite structure formation.

\section{Experimental Section}

Samples with different composition were prepared by solid phase synthesis from hematite (prepared at Regional Centre of Advanced Technologies and Materials in Olomouc) and cobalt chloride (prepared at Merck KGaA, Darmstadt, Germany). The required amount of cobalt chloride and hematite (Table 1) was mixed and crushed for approximately 10 minutes in an agate mortar. After adding $30 \mu \mathrm{l}$ of $0.1 \mathrm{M} \mathrm{HCl} 50 \mathrm{mg}$ of homogeneous mixture was placed into a laboratory furnace. To guarantee the same thermal treatment conditions, all the samples were placed into the furnace simultaneously. After being dried for one hour at $90{ }^{\circ} \mathrm{C}$ the samples were heated up to the temperature of $1000{ }^{\circ} \mathrm{C}$ with a rate of $30{ }^{\circ} \mathrm{C}$ per minute and annealed in static air atmosphere for 5 hours. In respect to radiation safety two sample series were prepared. The first series contained a radioactive ${ }^{57} \mathrm{Co}$, while the other was prepared with the use of a non-radioactive Co. In the case of radioactive samples, the $\mathrm{HCl}$ solution con- tained small amount of dissolved ${ }^{57} \mathrm{CoCl}$ with radionuclide purity of $99.8 \%$. Namely $10^{17}$ of radioactive atoms per $30 \mu \mathrm{l}$ of solution were incorporated inside the resulting material during the synthesis. The resulting activity of the samples was 1.1 MBq. The radioactive samples were used in transmission and emission Mössbauer experiments. Non-radioactive samples were used for other techniques, i.e. scanning electron microscopy and X-ray powder diffraction.

The studied samples, listed in Table 1, follow the notation $\mathrm{S} x$ where $x$ denotes the amount of cobalt in the formula $\mathrm{Co}_{x} \mathrm{Fe}_{3-x} \mathrm{O}_{4}$ assuming that all $\mathrm{Fe}$ and $\mathrm{Co}$ atoms are incorporated into the resulting ferrite. Samples prepared with radioactive cobalt are labelled by ${ }^{*}$. Sample $S 1.00^{168}$ was prepared using an annealing time of $168 \mathrm{~h}$. Observing only small differences between the sample $\mathrm{S} 1.00^{168}$ and S1.00 we can state that annealing time of $5 \mathrm{~h}$ was sufficient for incorporation of $\mathrm{Co}$ atoms to the structure and formation of ferrite.

The morphology of the samples was examined by Tescan VEGA3 LMU scanning electron microscope (SEM). The pictures were achieved using accelerating voltage of $20 \mathrm{kV}$. The crystal structure and phase composition of the samples were analysed by X-ray powder diffraction (XRD). Diffractometer with a cobalt X-ray lamp (Co Ka radiation $\lambda=1.79031 \AA$ ) operated in the Bragg-Brentano geometry in the $2 \theta$ angle range of $10-105^{\circ}$.

Mössbauer spectroscopy measurements were performed on MS96 virtual spectrometer ${ }^{37,38}$ in a constant acceleration regime. The used scintillation detector contained a crystal of sodium iodide activated by thallium. In transmission measurement, ${ }^{57} \mathrm{Co}$ in a rhodium matrix was utilized as a radiation source. In the emission arrangement, $\mathrm{K}_{2} \mathrm{MgFe}(\mathrm{CN})_{6}$ with $0.25 \mathrm{mg} / \mathrm{cm}^{2}$ of ${ }^{57} \mathrm{Fe}$ was employed as a reference absorber. The measuring time in the transmission and emission modes was approximately five and eleven days, respectively.

\section{Results and Discussion}

The morphology of the studied samples is shown in the SEM images in Figure 1. The S0.33 sample consisted of

Table 1. List of samples, cobalt and iron atomic ratios and the quantities of cobalt chloride and hematite used for the synthesis. The nominal amount of $\mathrm{Co}$ in the formula $\mathrm{Co}_{\mathrm{x}} \mathrm{Fe}_{3-\mathrm{x}} \mathrm{O}_{4}$ is denoted by $\mathrm{x}$. The samples prepared with radioactive ${ }^{57} \mathrm{Co}$ are labelled with *.

\begin{tabular}{ccccc}
\hline $\boldsymbol{x}$ & Sample & $\mathbf{A}_{\mathbf{X}}(\mathbf{C o}): \mathbf{A}_{\mathbf{X}}(\mathbf{F e})$ & Weight of $\mathbf{F e}_{\mathbf{2}} \mathbf{O}_{\mathbf{3}}(\mathbf{m g})$ & Weight of CoCl $\mathbf{2}(\mathbf{m g})$ \\
\hline 0.33 & $\mathrm{~S} 0.33, \mathrm{~S} 0.33^{*}$ & $0.25: 2.00$ & 100.0 & 20.3 \\
0.66 & $\mathrm{~S} 0.66, \mathrm{~S} 0.66^{*}$ & $0.50: 2.00$ & 90.0 & 36.5 \\
0.82 & $\mathrm{~S} 0.82, \mathrm{~S} 0.82^{*}$ & $0.75: 2.00$ & 80.0 & 48.7 \\
1.00 & $\mathrm{~S} 1.00, \mathrm{~S} 1.00^{*}, \mathrm{~S}_{1.00^{168}}$ & $1.00: 2.00$ & 79.8 & 64.9 \\
1.15 & $\mathrm{~S} 1.15, \mathrm{~S} 1.15^{*}$ & $1.25: 2.00$ & 60.0 & 60.9 \\
1.29 & $\mathrm{~S} 1.29, \mathrm{~S} 1.29^{*}$ & $1.50: 2.00$ & 50.0 & 60.9 \\
1.40 & $\mathrm{~S} 1.40, \mathrm{~S} 1.40^{*}$ & $1.75: 2.00$ & 50.0 & 71.1 \\
\hline
\end{tabular}


spherical particles of $200 \mathrm{~nm}$, see Figure 1a. There is a wide particle size distribution from 0.1 to $1 \mu \mathrm{m}$ for the sample S0.66 (Figure 1b). The further increase in the overall particle size was observed with rising concentration of Co in the samples (Figure 1c-f). The size of particles overcomes even $2 \mu \mathrm{m}$. Particles forming natural octahedrons typical for spinel structure can be seen in the SEM images (Figure 1d-h).

Figure 2 shows the diffraction patterns of all the samples. The structures belonging to cobalt ferrites, $\mathrm{Fe}_{2} \mathrm{O}_{3}$ and $\mathrm{Co}_{3} \mathrm{O}_{4}$ were identified in the diffraction patterns and their amounts were estimated using Rietveld analysis. The development of the individual phases can be observed in the range of diffraction patterns containing the cobalt ferrite (220), cobalt oxide (220) and hematite (104) reflections. The reflections show the gradual rise in the amount of cobalt ferrite with the increase of cobalt ratio inside the samples $\left(2 \theta=35.2^{\circ}\right)$. Similarly, the slight increase in the peak corresponding to cobalt oxide could be observed as well $\left(2 \theta=36.5^{\circ}\right)$. On the other hand, the amount of hematite followed the opposite trend and decreased $(2 \theta=$ $\left.38.7^{\circ}\right)$. For the samples S1.29 and 1.40 the broadening of reflections corresponding to the ferrite structure and their shift to higher angles may indicate lattice defects.
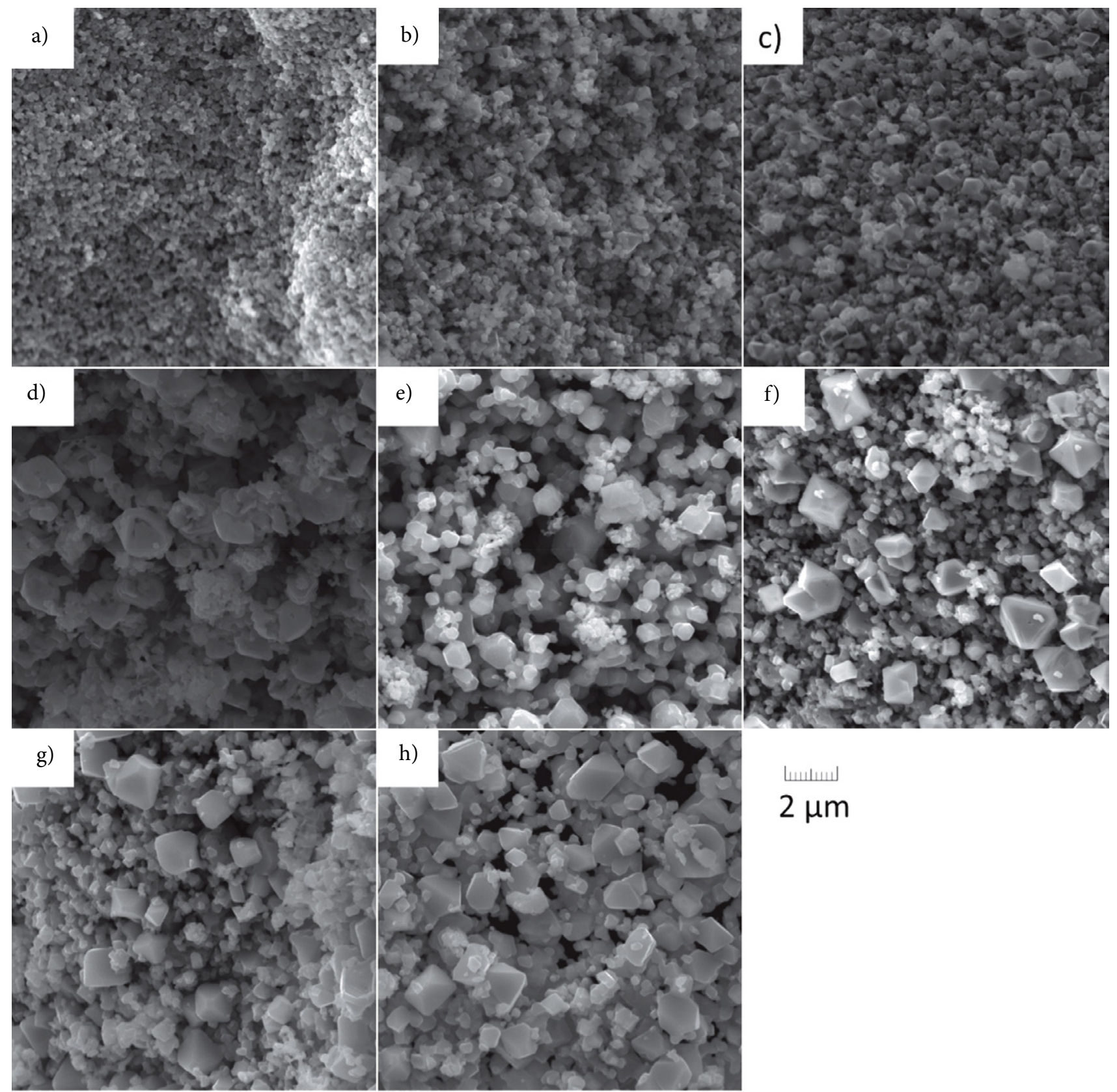

$2 \mu \mathrm{m}$

Figure 1. SEM images a) S0.33, b) S0.66, c) S0.82, d) S1.00, e) $S 1.00^{168}$, f) S1.15, g) S1.29, h) S1.40. 


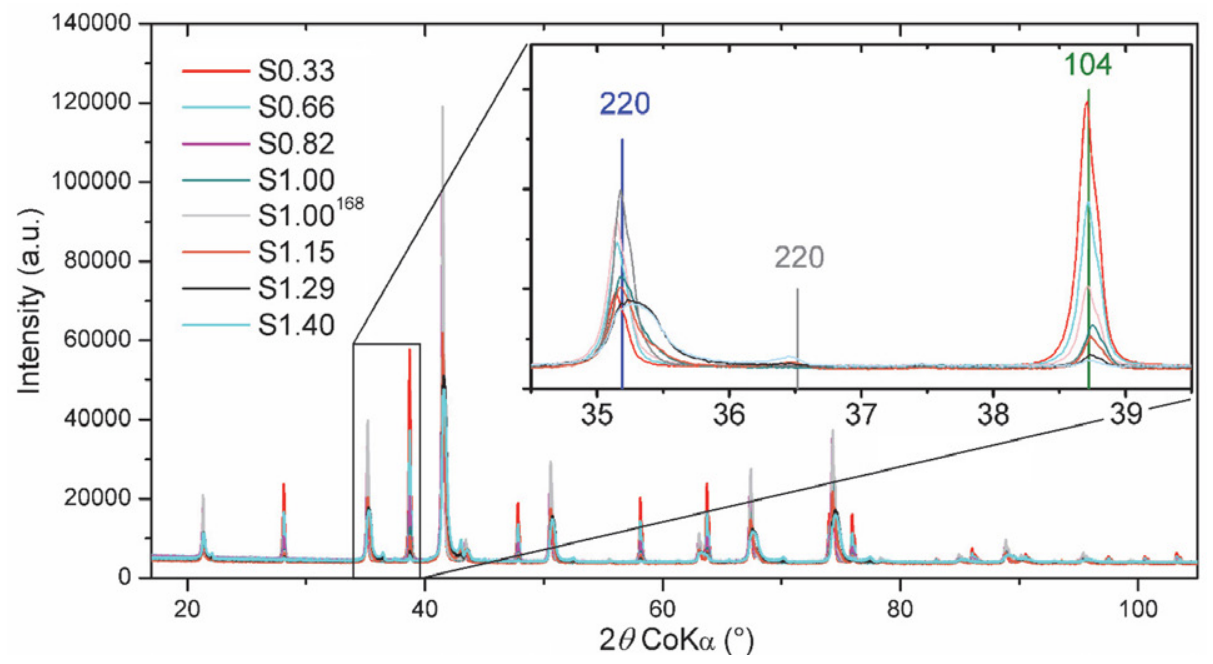

Figure 2. X-ray powder diffraction patterns for samples S0.33, S0.66, S0.82, S1.00, S1.00 ${ }^{168}, \mathrm{~S} 1.15, \mathrm{~S} 1.29$ and S1.40. The cobalt ferrite (220), cobalt oxide (220) and hematite (104) reflections are shown in detail in the upper-right corner. The positions of these reflections are marked by blue, grey and green vertical lines, respectively.

Figure 3 shows the dependence of the phase composition on cobalt concentration in the samples. The amount of cobalt ferrites rose with the increasing nominal Co concentration $x$, while the amount of hematite decreased. In addition to the shown samples, $7.5 \%$ of $\mathrm{Fe}_{2} \mathrm{O}_{3}$ and $92.5 \%$ of cobalt ferrites were determined for the sample $\mathrm{S} 1.00^{168}$.

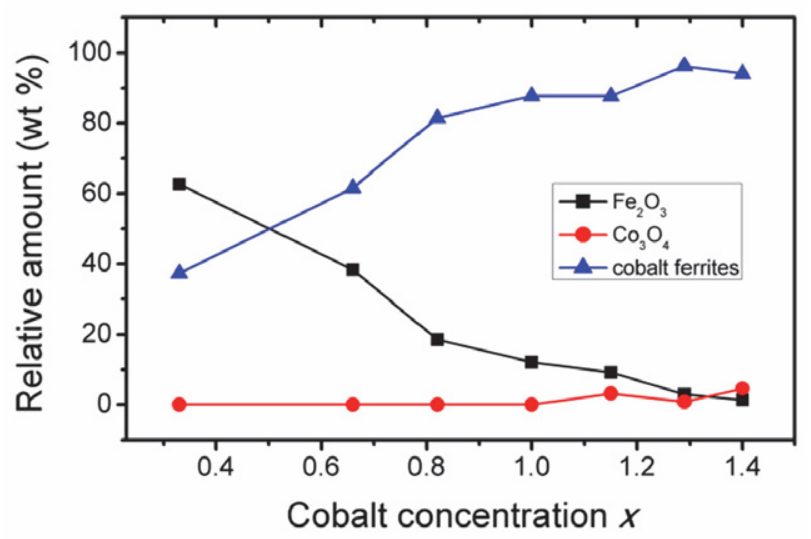

Figure 3. Mass percentage of individual phases in samples.

As can be seen in Figure 3, not all the Co atoms from $\mathrm{CoCl}_{2}$ were incorporated into the cobalt ferrite structure. Therefore, the nominal amount $x$ differs from the actual amount of Co in ferrite, denoted as $y$. The values of $y$ in $\mathrm{Co}_{\mathrm{y}} \mathrm{Fe}_{3-\mathrm{y}} \mathrm{O}_{4}$ were determined from mass ratios of cobalt ferrite, hematite and cobalt oxide obtained by XRD and from the inputs of the reaction. The resulting $y$ with respect to the nominal $x$ is shown in Figure 4 . It can be seen that for lower amounts of Co entering the reaction relatively low amount of ferrite with higher concentration of

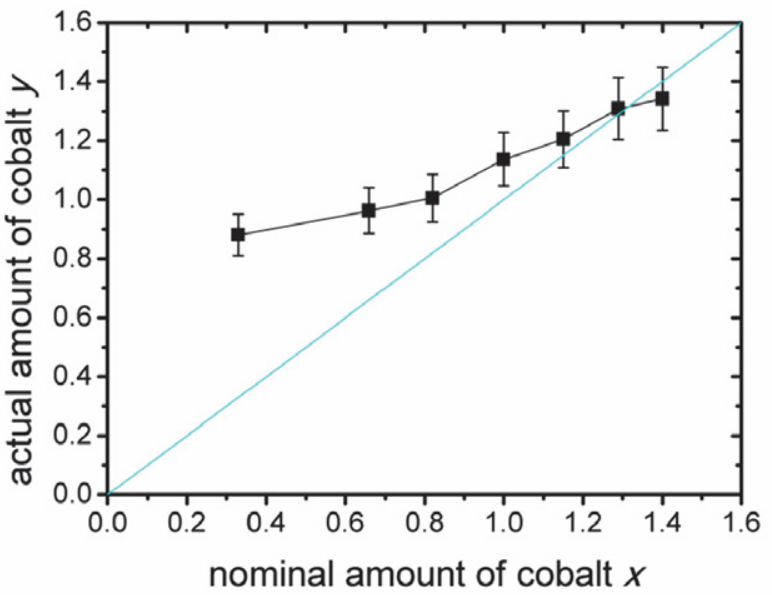

Figure 4. The actual amount of cobalt $y$ in ferrite $\mathrm{Co}_{y} \mathrm{Fe}_{3-\mathrm{y}} \mathrm{O}_{4}$ versus the nominal amount of cobalt $x$.

Co is formed. With increasing amount of Co entering the reaction the actual $y$ reaches the nominal $x$.

Figure 5 shows emission and transmission spectra of

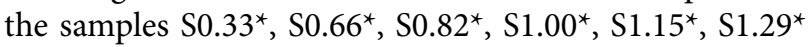
and $S 1.40^{*}$. All the spectra were normalized to unit area absorbed. The arrows in the figure 5 indicate the lines positions of $\mathrm{CoFe}_{2} \mathrm{O}_{4}$ and $\mathrm{Fe}_{2} \mathrm{O}_{3}$. They were calculated according to the hyperfine parameters listed in Table $2 .{ }^{11}$ The

Table 2. Hyperfine parameters of $\mathrm{CoFe}_{2} \mathrm{O}_{4} \mathrm{~A}$ and $\mathrm{B}$ site and hematite. $^{11}$

\begin{tabular}{lccc}
\hline & $\boldsymbol{\Delta}(\mathbf{m m} / \mathbf{s})$ & $\Delta \boldsymbol{E}_{\mathbf{Q}}(\mathbf{m m} / \mathbf{s})$ & $\boldsymbol{B}_{\mathbf{h f}}(\mathrm{T})$ \\
\hline $\mathrm{CoFe}_{2} \mathrm{O}_{4}(\mathrm{~A})$ & 0.29 & -0.01 & 48.78 \\
$\mathrm{CoFe}_{2} \mathrm{O}_{4}(\mathrm{~B})$ & 0.36 & 0.01 & 51.64 \\
Hematite & 0.37 & -0.19 & 51.75 \\
\hline
\end{tabular}



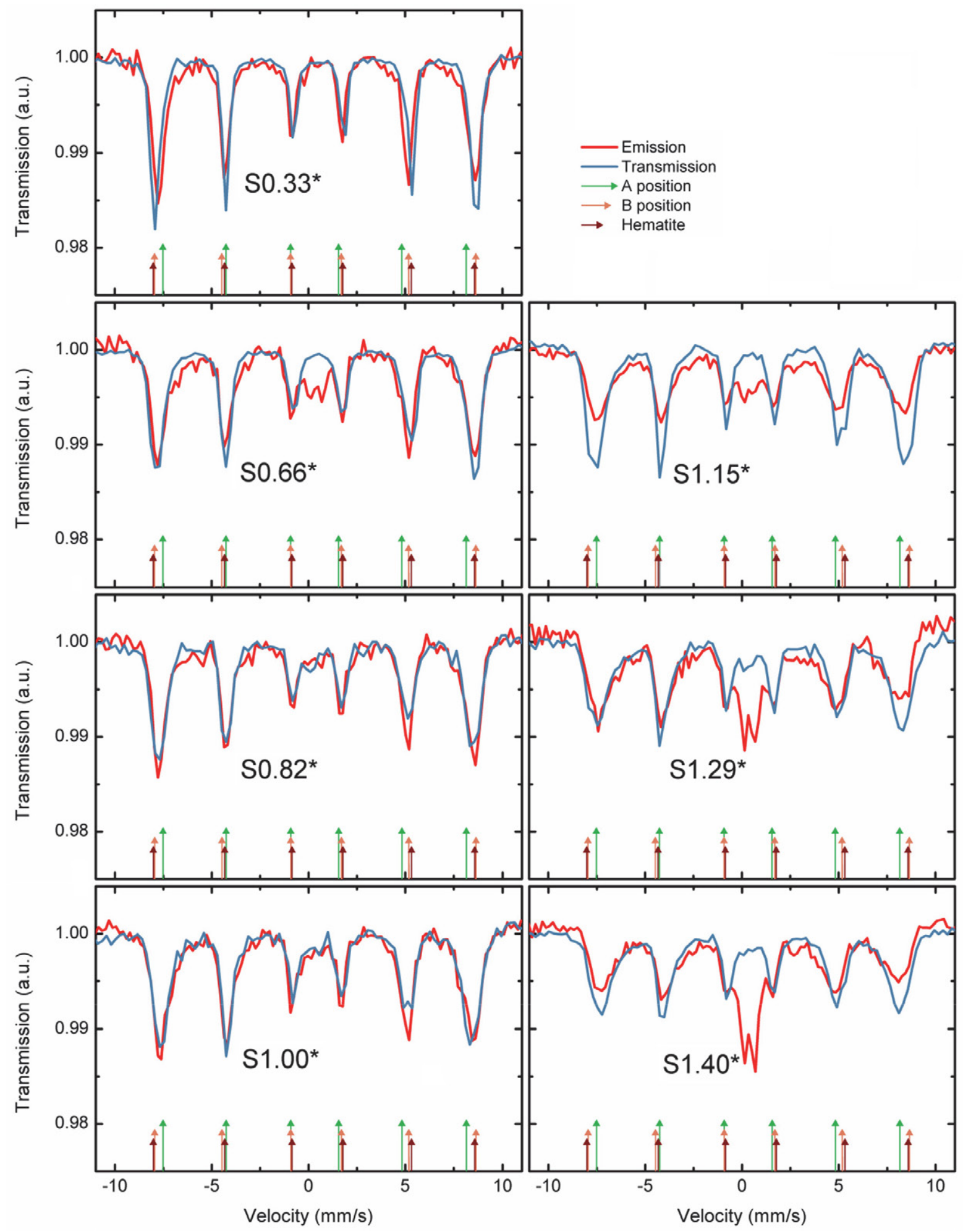

Figure 5. Emission and transmission spectra of samples $\mathrm{S} 0.33^{*}, \mathrm{~S} 0.66^{*}, \mathrm{~S} 0.82^{*}, \mathrm{~S} 1.00^{*}, \mathrm{~S} 1.15^{\star}, \mathrm{S} 1.29^{*}$ and $\mathrm{S} 1.40^{*}$. The arrows indicate the lines positions of $\mathrm{CoFe}_{2} \mathrm{O}_{4}$ (A and $\mathrm{B}$ positions) and $\mathrm{Fe}_{2} \mathrm{O}_{3}$.

difference between emission and transmission spectrum of sample $\mathrm{S}_{0.33^{*}}$ is caused by the presence of excess hematite in the sample. Hematite contributed only to a transmission spectrum because it contains no ${ }^{57} \mathrm{Co}$.
The doublet in the emission spectra, positioned at the centre of the measured area, was ascribed to ${ }^{57} \mathrm{Co}$ atoms incorporated into the structure of cobalt oxide. There was also an evident line broadening in the case of samples 


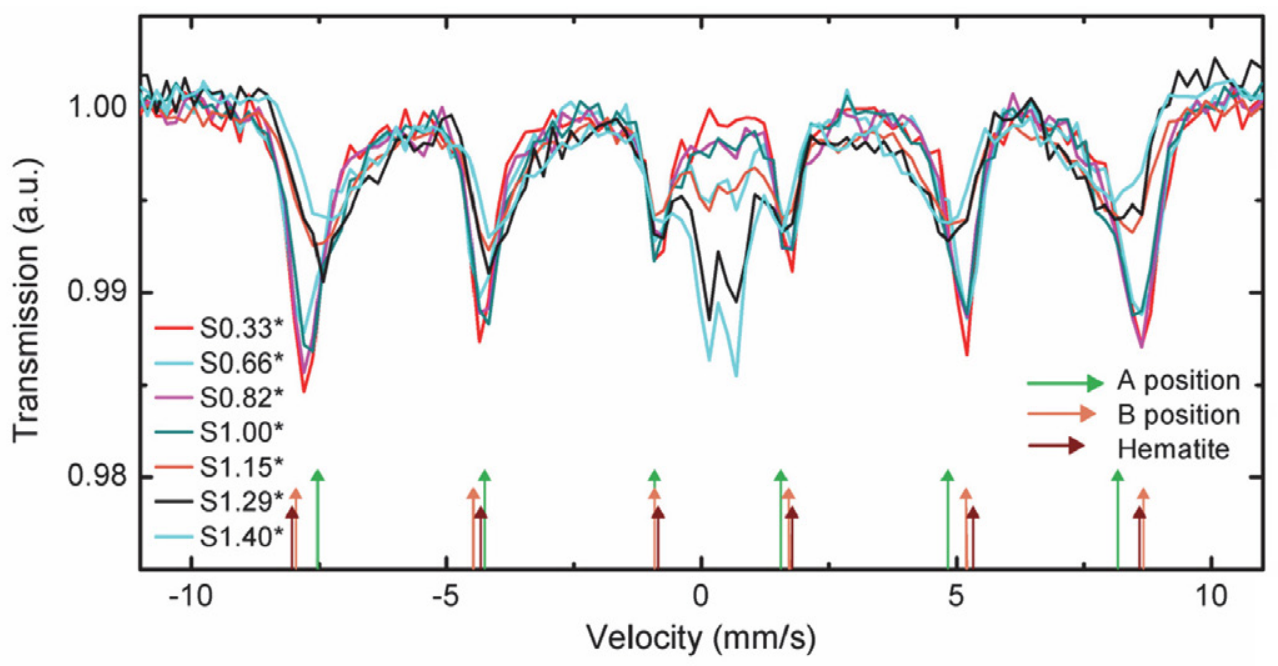

Figure 6. Emission spectra of $\mathrm{S} 0.33^{*}, \mathrm{~S} 0.66^{*}, \mathrm{~S} 0.82^{*}, \mathrm{~S} 1.00^{*}, \mathrm{~S} 1.15^{*}, \mathrm{~S} 1.29^{*}$ and $\mathrm{S} 1.40^{*}$ samples.

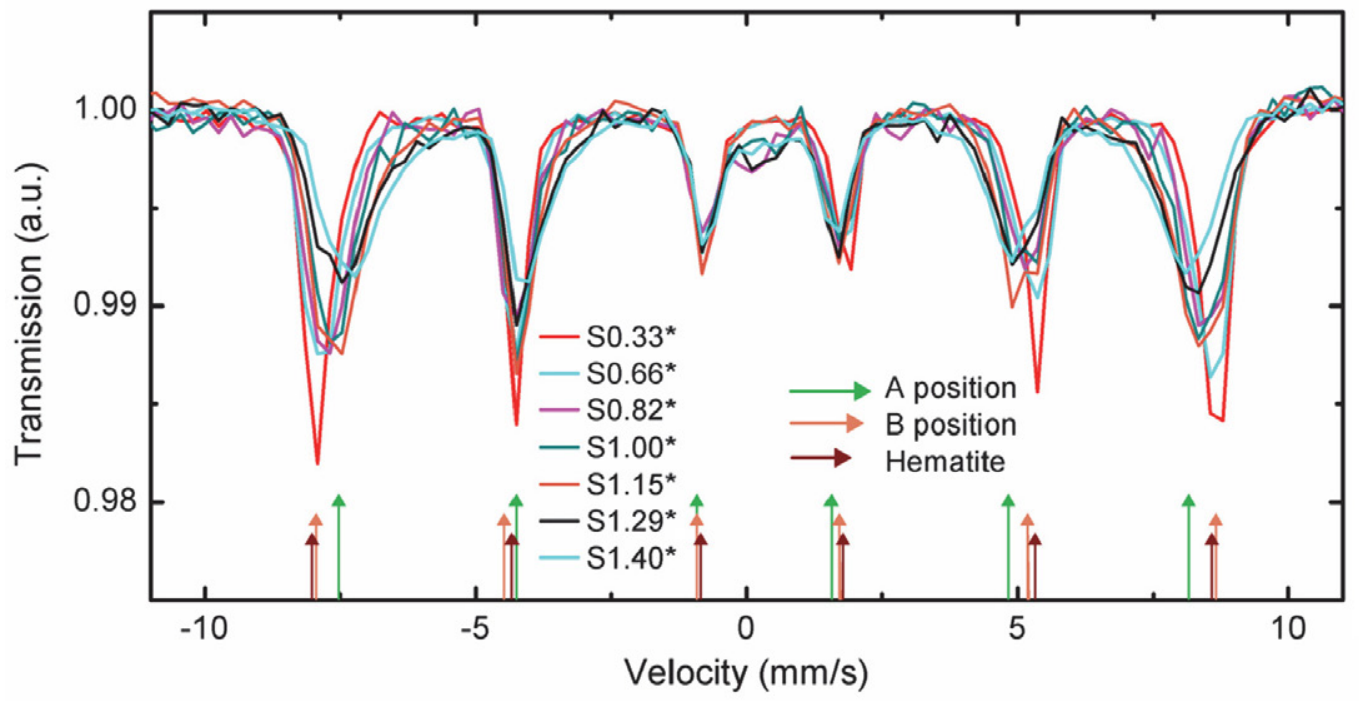

Figure 7. Transmission spectra of $\mathrm{S} 0.33^{*}, \mathrm{~S} 0.66^{*}, \mathrm{~S} 0.82^{*}, \mathrm{~S}_{1.00^{*}}, \mathrm{~S} 1.15^{*}, \mathrm{~S} 1.29^{*}$ and $\mathrm{S} 1.40^{*}$ samples.

S1.29* and $\mathrm{S} 1.40^{*}$ which indicates an occurrence of a distribution of hyperfine magnetic field. That is in accordance with the observation of line broadening in X-ray powder diffraction patterns for samples S1.29 and S1.40. Likely, the higher amount of Co caused higher disorder in the ferrite lattice.

Figure 6 compares the emission spectra of samples S0.33*, S0.66*, S0.82*, S1.00*, S1.15*, S1.29*, and S1.40*. One could clearly see a change in the distribution of hyperfine magnetic field with the increasing Co concentration. The spectral lines get broader and shift to lower energies.

Figure 7 shows transmission Mössbauer spectra of S0.33*, S0.66*, S0.82*, S1.00*, S1.15*, S1.29* and S1.40* samples. Similarly to the emission spectra, there was a shift in the positions of the spectral lines as well as the change in their shape with the increasing concentration of cobalt.
Comparing the transmission and emission spectra, it can be concluded that the formed cobalt ferrites did not exhibit the inverse spinel structure. In the case of the inverse spinel structure the Co atoms would occupy only the $\mathrm{B}$ positions. This would cause an observable difference between the magnetic contribution to the emission and transmission Mössbauer spectra as only the B position spectral lines would occur in the former. However, in our case the line positions of emission and transmission spectra for individual samples did not exhibit any significant differences. This is typical for a uniform distribution of cobalt and iron atoms in the $\mathrm{A}$ and $\mathrm{B}$ positions, leading to a mixed spinel structure described by a formula $\left(\mathrm{Co}_{0.33 y} \mathrm{Fe}_{1-0.33 y}\right)\left[\mathrm{Co}_{0.66 y} \mathrm{Fe}_{2-0.66 y}\right] \mathrm{O}_{4}$. Therefore, the measured data suggest that the $\mathrm{A}$ and $\mathrm{B}$ positions occupation approaches the uniform distribution. For samples with the cobalt concentration $y$ close to 1 this would lead to a classic 
formula $\left(\mathrm{Co}_{1-\delta} \mathrm{Fe}_{\delta}\right)\left[\mathrm{Co}_{\delta} \mathrm{Fe}_{2-\delta}\right] \mathrm{O}_{4}$, where the degree of inversion $\delta$ equals 0.66 . Small differences between the emission and transmission spectra can be ascribed to the presence of hematite (samples $\mathrm{S}^{*} .33^{*}$ and $\mathrm{S} 0.66^{*}$ ) or cobalt oxide (samples S0.66* ${ }^{\star} \mathrm{S} 1.15^{\star}, \mathrm{S} 1.29^{\star}$ and $\mathrm{S} 1.40^{\star}$ ).

\section{Conclusion}

In this work, the samples of cobalt ferrites containing various amount of $\mathrm{Co}$ atoms were prepared by a solid-state reaction of hematite and cobalt chloride. The relative amount of cobalt in the ferrite structure was obtained by XRD. The relatively small amount of cobalt ferrite with higher concentration of Co was observed for lower number of Co atoms entering the reaction. A novel approach of comparing the results from transmission and emission Mössbauer spectroscopy allows to follow the formation of cobalt ferrites in more detail. Namely, it suggests that cations distribution in the ferrite structure approaches the uniform distribution according to the formula $\left(\mathrm{Co}_{0.33 y}\right.$ $\left.\mathrm{Fe}_{1-0.33 y}\right)\left[\mathrm{Co}_{0.66 y} \mathrm{Fe}_{2-0.66 y}\right] \mathrm{O}_{4}$. For samples whose relative ratios of cobalt and iron atoms were close to 1:2 the degree of inversion was close to $\delta=0.66$.

\section{Acknowledgement}

The authors gratefully acknowledge the financial support from the internal IGA grant of Palacký University (IGA_PrF_2019_002 and IGA_PrF_2019_023). Authors would also like to thank Ivo Medŕík for preparation of hematite powder, Josef Kaslik for XRD measurements and Helena Sedláčková for her help with the paper.

\section{References}

1. D. S. Mathew, R. Juang, Chem. Eng. J. 2007, 129, 51-65. DOI:10.1016/j.cej.2006.11.001

2. P. Lavela, J. L. Tirado, J. Power Sources 2007, 172, 379-387. DOI:10.1016/j.jpowsour.2007.07.055

3. I. Sharifi, H. Shokrollahi, S. Amiri, J. Magn. Magn. Mater. 2012, 324, 903-915. DOI:10.1016/j.jmmm.2011.10.017

4. S. Amiri, H. Shokrollahi, Mater. Sci. Eng. C 2013, 33, 1-8. DOI:10.1016/j.msec.2012.09.003

5. A. Manikandan, R. Sridhar, S. A. Antony, S. Ramakrishna, J. Mol. Struct. 2014, 1076, 188-200.

DOI:10.1016/j.molstruc.2014.07.054

6. P. D. Prasad, J. Hemalatha, J. Magn. Magn. Mater. 2019, 484, 225-233. DOI:10.1016/j.jmmm.2019.04.026

7. O. Caltun, I. Dumitru, M. Feder, N. Lupu, H. Chiriac, J. Magn. Magn. Mater. 2008, 320, 869-873.

DOI:10.1016/j.jmmm.2008.04.067

8. M. Gharibshahian, O. Mirzaee, M. S. Nourbakhsh, J. Magn. Magn. Mater. 2017, 425, 48-56.

DOI:10.1016/j.jmmm.2016.10.116
9. A. B. Salunkhe, V. M. Khot, N. D. Thorat, M. R. Phadatare, C. I. Sathish, D. S. Dhawale, S. H. Pawar, Appl. Surf. Sci. 2013, 264, 598-604. DOI:10.1016/j.apsusc.2012.10.073

10. M. Kooti, S. Gharineh, M. Mehrkhah, A. Shaker, H. Motamedi, Chem. Eng. J. 2015, 259, 34-42.

DOI:10.1016/j.cej.2014.07.139

11. Z. P. Niu, Y. Wang, F. S. Li, Phys. Status Solidi B 2010, 247, 198-201. DOI:10.1002/pssb.200945455

12. M. Eshraghi, P. Kameli, Curr. Appl. Phys. 2011, 11, 476-481. DOI:10.1016/j.cap.2010.08.032

13. J. Wang, T. Deng, Y. Lin, C. Yang, W. Zhan, J. Alloys Compd. 2008, 450, 532-539. DOI:10.1016/j.jallcom.2007.02.099

14. R. J. Hill, J. R. Craig, G. V Gibbs, Phys. Chem. Miner. 1979, 4, 317-339. DOI:10.1007/BF00307535

15. D. Carta, M. F. Casula, A. Falqui, D. Loche, G. Mountjoy, C. Sangregorio, A. Corrias, J. Phys. Chem. C 2009, 4, 8606-8615. DOI:10.1021/jp901077c

16. V. G. Patil, S. E. Shirsath, S. D. More, S. J. Shukla, K. M. Jadhav, J. Alloys Compd. 2009, 488, 199-203.

DOI:10.1016/j.jallcom.2009.08.078

17. R. Pandit, K. K. Sharma, P. Kaur, R. Kumar, Mater. Chem. Phys. 2014, 148, 988-999.

DOI:10.1016/j.matchemphys.2014.09.009

18. P. C. R. Varma, R. Sekhar, D. Banerjee, M. Raama, K. G. Suresh, A. K. Nigam, J. Alloys Compd. 2008, 453, 298-303. DOI:10.1016/j.jallcom.2006.11.058

19. A. J. Franco, E. C. de O. Lima, M. A. Novak, P. R. J. Wells, J. Magn. Magn. Mater. 2007, 308, 198-202.

DOI:10.1016/j.jmmm.2006.05.022

20. M. S. Khandekar, R. C. Kambale, J. Y. Patil, Y. D. Kolekar, S. S. Suryavanshi, J. Alloys Compd. 2011, 509, 1861-1865.

DOI:10.1016/j.jallcom.2010.10.073

21. R. C. Kambale, P. A. Shaikh, N. S. Harale, V. A. Bilur, Y. D. Kolekar, C. H. Bhosale, K. Y. Rajpure, J. Alloys Compd. 2010, 490, 568-571. DOI:10.1016/j.jallcom.2009.10.082

22. Y. Zhang, Z. Yang, D. Yin, Y. Liu, C. Fei, R. Xiong, J. Shi, G. Yan, J. Magn. Magn. Mater. 2010, 322, 3470-3475.

DOI:10.1016/j.jmmm.2010.06.047

23. E. Mendelovici, R. Villalba, A. Sagarzazu, Thermochim. Acta 1998, 318, 51-56. DOI:10.1016/S0040-6031(98)00329-3

24. Z. Karimi, Y. Mohammadifar, H. Shokrollahi, S. Khameneh, G. Youse, L. Karimi, J. Magn. Magn. Mater. 2014, 361, 150156. DOI:10.1016/j.jmmm.2014.01.016

25. A. Repko, J. Vejpravová, T. Vacková, D. Zákutná, D. Nižňanský, J. Magn. Magn. Mater. 2015, 390, 142-151.

DOI:10.1016/j.jmmm.2015.04.090

26. X. Li, C. Xu, X. Han, L. Quiao, T. Wang, F.-S. Li, Nanoscale Res. Lett. 2010, 5, 1039-1044.

DOI:10.1007/s11671-010-9599-9

27. L. J. Cote, A. S. Teja, A. P. Wilkinson, Z. J. Zhang, Fluid Phase Equilib. 2003, 210, 307-317.

DOI:10.1016/S0378-3812(03)00168-7

28. T. Dippong, E. A. Levei, O. Cadar, F. Goga, L. Barbu-Tudoran, J. Anal. Appl. Pyrolysis 2017, 128, 121-130.

DOI:10.1016/j.jaap.2017.10.018 
29. T. Dippong, E. A. Levei, O. Cadar, F. Goga, L. Barbu-Tudoran, G. Borodi, J. Therm. Anal. Calorim. 2017, 128, 39-52.

DOI:10.1007/s10973-016-5930-8

30. I. Sharifi, H. Shokrollahi, M. Mahdi, R. Safi, J. Magn. Magn. Mater. 2012, 324, 1854-1861.

DOI:10.1016/j.jmmm.2012.01.015

31. S. Rana, J. Philip, B. Raj, Mater. Chem. Phys. 2010, 124, 264269. DOI:10.1016/j.matchemphys.2010.06.029

32. H. S. C. O'Neill, A. Navrotsky, Am. Mineral. 1983, 68, 181194.

33. G. A. Petitt, D. W. Forester, Phys. L Rev. B 1971, 4, 3912-3923.

DOI:10.1103/PhysRevB.4.3912
34. G. A. Sawatzky, F. Van Der Woude, A. H. Morrish, Phys. Rev. 1969, 187, 747-757. DOI:10.1103/PhysRev.187.747

35. Z. Szotek, W. M. Temmerman, D. Ködderitzsch, A. Svane, L. Petit, H. Winter, Phys. Rev. B 2006, 74, 1-12.

DOI:10.1103/PhysRevB.74.174431

36. Y. H. Hou, Y. J. Zhao, Z. W. Liu, H. Y. Yu, X. C. Zhong, W. Q. Qiu, D. C. Zeng, L. S. Wen, J. Phys. D. Appl. Phys. 2010, 43, 445003. DOI:10.1088/0022-3727/43/44/445003

37. J. Pechoušek, D. Jančík, J. Frydrych, J. Navařík, P. Novák, AIP Conf. Proc. 2012, 1489, 186-193.

38. J. Pechousek, R. Prochazka, D. Jancik, J. Frydrych, M. Mashlan, J. Phys. Conf. Ser. 2010, 217, 012006 (4).

DOI:10.1088/1742-6596/217/1/012006

\section{Povzetek}

$\mathrm{V}$ študiji se osredotočamo na urejanje kobalta in železa znotraj feritne strukture $\mathrm{Co}_{\mathrm{x}} \mathrm{Fe}_{3-\mathrm{x}} \mathrm{O}_{4}$. Spojine smo pripravili $\mathrm{z}$ reakcijami v trdnem stanju med $\alpha-\mathrm{Fe}_{2} \mathrm{O}_{3}$ and $\mathrm{CoCl}_{2}$. Za selektivno preverjanje položaja železovih in kobaltovih atomov v strukturi smo uporabili kombinacijo transmisijske in emisijske Mössbauerjeve spektroskopije. S primerjavo transmisijskih in emisijskih spektrov smo lahko določili zasedenost tetraedrskih in oktaedrskih položajev. Predstavljena metoda združevanja teh dveh tehnik Mössbauerjeve spektroskopije je primerna za katero koli spojino, ki vsebuje železove in kobaltove atome. Dodatne informacije glede sestave in morfologije vzorcev smo dobili z rentgensko prašno difrakcijo in z vrstično elektronsko mikroskopijo (SEM). Ob uporabi večje množine Co v reakciji, se je povečala tudi stopnja vgradnje atomov Co v strukturo ferita.

Except when otherwise noted, articles in this journal are published under the terms and conditions of the Creative Commons Attribution 4.0 International License 